\title{
A Boom in Private Secondary Education in Cross River State, Nigeria: Causes and Consequences on the Education System
}

\author{
Dr. Joseph E. Ogbiji \\ Josephogbij@yahoo.com \\ Mr. Sylvanus A. Ogbiji \\ Faculty of Education, Cross River University of Technology, Calabar
}

Doi:10.5901/jesr.2014.v4n6p485

\section{Abstract}

This study investigated the causes and consequences of a boom in private secondary education in cross river state, Nigeria, in the first decade of the $21^{\text {st }}$ millennium. A 30 item research instrument was designed by the researchers based on the four null hypotheses that guided the research. The hypotheses were based on the social, political and economic factors during the period that could give rise to the establishment of private secondary schools as well as the consequences of such a development on the education system. Result from the samples of two hundred school managers from both public and private secondary schools showed that hypotheses one and four were retained, while two and three were rejected. This implied that managers of both public and private secondary schools do not differ significantly on the social factors that gave rise to a boom in private secondary schools as well as the consequences of the development on the education system. School managers of the two divide however differ significantly on their perception of the political and economic factors that gave rise to the proliferation of private secondary schools during the period.

\section{Introduction}

Western education started in Nigeria in 1843 (Fafunwa, 2004). This was after the abolition of the Trans Atlantic slave trade in Europe in 1807. Fafunwa (2004) pointed out that the major actors in the establishment of modern education in Nigeria were the Christian missions. Prominent among them were the Church Missionary Society (CMS), the Roman Catholic Mission (RCM), the Methodist Church and the Baptist church. Below are some of the early missionary school established in Nigeria as recorded by Fafunwa (2004) and Okunola, Oyabede and Oladipo (2005)

Fig. 1: Some early Mission schools in Nigeria by date and location

\begin{tabular}{|l|l|c|l|}
\hline Institution & Location & Date founded & Agency \\
\hline Methodist primary school & Badagry-Lagos & 1843 & Methodist \\
\hline CMS primary school & Abeokuta & 1846 & Church Missionary Society \\
\hline Duke Town Primary School & Calabar & 1846 & Church of Scotland Mission \\
\hline CMS grammar school & Lagos & 1859 & Church Missionary Society \\
\hline CMS teacher training college & Abeokuta & 1849 & Church Missionary Society \\
\hline St. Gregory's College & Lagos & 1876 & Church Missionary Society \\
\hline Methodist Boys high School & Lagos & 1876 & Methodist \\
\hline Roman Catholic Mission Primary School & Lagos & 1868 & Roman Catholic church \\
\hline Methodist Girls high School & Lagos & 1879 & Methodist \\
\hline Baptist Primary School & Ogbomosho & 1854 & Baptist \\
\hline Hope Waddell training Institution & Calabar & 1895 & Church of Scotland Mission \\
\hline St. Andrew's College & Oyo & 1896 & Church Missionary Society \\
\hline Baptist training college & Ogbomosho & 1897 & Baptist \\
\hline St. Paul's College & Awka & 1904 & Church Missionary Society \\
\hline Oron training Institution & Oron & 1905 & Primitive church \\
\hline
\end{tabular}

The major objectives of establishing schools by the missionary bodies were to win young converts to their faith, produce 
literate adherents who will assist them in evangelism and establish an effective means of communication through the teaching of English Language (Tabotndip, 2010). Hence the curriculum of the early schools centred on reading, writing and arithmetic.

The British colonial administration in Nigeria at its inception was not keen over the education of the citizenry. It could be pointed out that effective British colonial administration of Nigeria started in 1861 when Dosumo, king of Lagos, signed a treaty, surrendering his sovereignty to the British Crown (Ukeje, 1992:5) It was only from 1882 that the British colonial administration in west Africa indicated palpable concern for the education of Africans by introducing the first education ordinance. The ordinance was aimed at introducing some control measures over the education system that lacked clear objectives and uniform curriculum. The ordinance brought about the setting up of education board, inspectorate units, grant-in-aid to voluntary agency schools and establishment of government -owned schools. Despite government intervention in the education system, the Phelps Stokes Commission Report of 1922 still severely criticized colonial government's attitude toward Western education in Nigeria which remained largely the concern of the Christian missions and other voluntary agencies until Nigeria's political independence in October 1960 (Ogbonnaya, 2010).

Active government participation on western education in Nigeria came into force only when Nigerians were given the political power to determine their own destiny. This started with the regionalization of Nigeria in the 1950s, when the Western and Eastern Regions declared free primary education for their people. The Ashby commission Report of 1959, which projected Nigeria's man-power need at independence in 1960 also gave Philip to government active participation in education as it recommended active government involvement in human resources development (Obi, 2004). At independence in 1960, the indigenous politicians saw education as a national priority and as such promoted and developed education through opening of government primary and secondary schools, establishment of universities, giving of scholarship and bursaries to students and creating employment opportunities for school leavers. In 1970 government took over all schools from private proprietorship and in 1976 declared universal free primary education (UPE) for the whole country (Enaohwo, 2006).

Following the astronomical rise in school enrolment on account of the UPE programme, government came to realize that educating the entire citizenry was a daunting task that required the involvement of the private sector as well; hence the liberalization of education for private sector participation. However, the call for private investment in education was received with apprehension until the dawn of the $21^{\text {st }}$ century (2000). But from the year 2000 to the present date the researchers have noticed a recrudescence of interest in private sector education initiative and a concomitant proliferation of private educational institutions at all levels of the education continuum.

The new crop of private schools which are owned mostly by individual investors, according to Osakwe (1992) and Onyiuke, (2000) are fraught with inadequacies ranging from insufficient and substandard accommodation, lack of adequate facilities for teaching-learning, teaching staff insufficiency to poor curriculum implementation. Tabotndip (2004) also added that many private schools operate in residential houses, unfinished buildings, community halls and church premises, without equipment or facilities required of schools, and with curricular that are inconsistent with the national curriculum. Onuka (2005) found out that in Oyo state, Nigeria, private primary and secondary schools were lacking in quality of teachers, facilities and management. He found out that 60 percent of teachers in private schools were unqualified, 80 percent of the buildings were inadequate and 73 percent of the schools were lacking in sports facilities. He however commended teachers of these schools for their regularity, punctuality and effectiveness which scored 80, 87 and 93 percent respectively.

In cross river state, Nigeria, where this study is domiciled, statistics from the ministry of education (2013), showed that there were 1,028 and 334 public primary and secondary schools respectively. The same source further reveal that there were 463 and 349 government approved private primary and secondary schools respectively. The source also revealed that there were several unapproved schools in existence in the state. Of the expected 410,506 secondary school enrolment in a state with a population of $3.5 \mathrm{~m}$ people, there were only 111,000 pupils in public secondary schools, leaving the rest to private schools and out-of-school population which is unknown. Information from the Ministry of education also reveals that between the year 2000-2005 the state scored less than 10\% in West African School Certificate examination. Records from the Ministry of Education (2013) showed that by 1999 there were less than 50 approved private secondary schools in the state. But between the year 2000 and 2013 the number of approved private secondary schools has risen to 349 . This is more than 600 percent increase in just about a decade!

\subsection{Statement of the problem}

It is difficult to explain or decifer factors that gave vent to the unprecedented rise in private secondary school population 
in Cross River State in just a decade.

\subsection{Specific objective of the study}

The study aimed at determining the factors that gave rise to the astronomical increase in the population of private secondary schools in Cross River State, using the social, political and economic indices in the period under study, and as well determine the consequences of the development on the education system in the state

\subsection{Research questions}

The study sought to provide answers to the following questions.

1) To what extent do principals of public secondary schools and proprietors of private secondary schools differ in their perception of social factors responsible for the resurgence of private secondary schools in Cross River State in the period under study?

2) To what extent do proprietors of private secondary schools and principals of public secondary schools differ in their perception of political factors as responsible for the boom in private secondary education in the period under study?

3) To what extent do proprietors of private secondary schools and principals of public secondary school differ in their perception of economic factors as being behind the resurgence of private secondary schools in the period under study in cross river state?

4) To what extent do principals of public secondary schools and proprietors of private secondary schools in cross river state differ in their perception of the consequences of the resurgence of private secondary schools on the education system in the state?

\section{Research Hypotheses}

The hypotheses that guided the study are as follows;

1. School managers do not differ significantly in their perception of social factors as influencing a boost in private secondary schools in Cross River State.

2. Proprietors of private secondary schools and principals of public secondary schools do not differ significantly in their perception of political factors as responsible for the boom in private secondary education system in Cross River State.

3. The perception of economic factors as being behind the resurgence of private secondary education does not significantly differ between proprietors of private secondary schools and principals of public secondary schools in Cross River State.

4. Principals of public secondary schools and proprietors of private secondary schools in Cross River State do not significantly differ in their perception of the consequences of the resurgence of private secondary schools on the education system.

\section{Methodology}

The study adopted ex-post facto or causal comparative design. This is so because the researchers sought to establish the cause-effect relationship of the boom in private secondary education in cross river state of Nigeria, in the period understudy. This is done through sampling the perception of $100(28.7 \%)$ proprietors of private secondary school and $100(29.9 \%)$ principals of public secondary schools through the researchers-made instrument. The instrument tagged "Boom in private secondary education Questionnaire (BIPSED)" composed of two parts. Part "A" sought the bio-data of the respondents such as status, sex and educational qualification while Part "B" which comprised of 30 items centred on sampling perceived opinion of respondents on how socio-economic and political conditions in the state could have given rise to a boom in private secondary education system and its possible effect on the education system as a whole. The social, political, economic factors and consequences carry 11, 7, 7, 5 items respectively.

Stratified random sampling technique was adopted by the researchers in administering the research instrument on the respondents. This was done through direct delivery technique. Despite this approach, 188 instrument were filled and returned, 92 from proprietors and 96 from principals, giving a return rate of 94 percent. Data was analyzed using 
independent t-test.

\section{Presentation of Results}

Hypothesis testing was carried out at .05 probability level. The hypothesis by hypothesis presentation of result are as follows.

\subsection{Hypothesis-by-hypothesis presentation of results}

Each hypothesis was re-stated in the null form for purposes of statistical testing. The test was carried out at.05 probability level.

\subsubsection{Hypothesis One}

"School managers do not differ significantly in their perception of social factors as influencing a boost in private secondary schools".

Table 1: Independent t-test analysis of difference between school managers in their perception of social factors as influencing a boost in private secondary schools $(\mathrm{N}=188)$

\begin{tabular}{lcccc}
\hline School managers & $\mathbf{N}$ & $\overline{\mathbf{X}}$ & $\mathbf{S . D .}$ & $\mathbf{t}$ \\
Proprietors of private secondary schools & 96 & 25.2 & 3.99 & -14.6 \\
Principals of public secondary schools & 92 & 31.6 & 3.03 & \\
\hline
\end{tabular}

Not significant at .05 , critical- $t=1.972, \mathrm{df}=186$

The independent t-test statistical procedure was applied in testing this hypothesis.

The result of the analysis as presented in Table 1 showed that the calculated t-value of -14.564 is less than the critical t-value of 1.972 at .05 probability level with 186 degree of freedom. Thus, the null hypothesis was retained. This implied that school managers do not differ significantly in their perception of social factors as influencing a boost in private secondary schools.

\subsubsection{Hypothesis two}

"Proprietors of private secondary schools and principals of public secondary schools do not different significantly in their perception of political factors as responsible for the boom in private secondary education system.

Table 2: Independent t-test analysis of difference between school managers in their perception of political factors as responsible for the boom in private secondary education system $(\mathrm{N}=188)$

\begin{tabular}{lcccc}
\hline School managers & $\mathbf{N}$ & $\overline{\mathbf{x}}$ & $\mathbf{S . D}$. & $\mathbf{t}$ \\
Proprietor of private secondary schools & 96 & 21.5 & 2.2 & $14.251^{*}$ \\
Principals of public secondary schools & 92 & 16.8 & 2.4 & ${ }^{*}$ \\
\hline
\end{tabular}

${ }^{*}$ Significant at .05, critical-t $=1.972, \mathrm{df}=186$

The independent t-test analysis technique was used in testing this hypothesis. The results as presented in table 2 indicated a t-calculated value of 14.251 which is greater than the critical-t ratio of 1.972 . Thus, the null hypothesis was rejected. This implied that, proprietors of private secondary schools and principals of public secondary schools differ significantly in their perception of political factors as responsible for the boom in private secondary education system.

\subsubsection{Hypothesis Three}

"The perception of economic factors as being behind the resurgence of private secondary education does not significantly differ between proprietors of private secondary schools and principals of public secondary schools". 
Table 3: Independent t-test of difference in the perception of economic factors as being behind the resurgence of private secondary education between school managers in private and public secondary schools $(\mathrm{N}=188)$

\begin{tabular}{lcccc}
\hline School managers & $\mathbf{N}$ & $\overline{\mathbf{x}}$ & S.D. & $\mathbf{t}$ \\
Proprietor of private secondary schools & 96 & 22.14 & 1.7 & $16.572^{\star}$ \\
Principals of public secondary schools & 92 & 17.37 & 2.2 & \\
\hline * Significant at .05, critical-t = 1.972, df = 186 & & & &
\end{tabular}

The independent t-test statistical procedure was applied in testing this hypothesis. The result of the analysis as presented in table 3 indicated a calculated t-value of 16.572 greater than the critical t-value of 1.972 at .05 probability level with 186 degree of freedom. Thus, the null hypothesis was rejected. This implied that the perception of economic factors as being behind the resurgence of private secondary education significantly differ between school managers in private and public secondary schools.

\subsubsection{Hypothesis four}

"Principals of public secondary schools and proprietors of private secondary schools do not significantly differ in their perception of the consequences of the resurgence of private secondary school on the education system in the state"

Table 4: Independent t-test analysis of difference in school manager's perception of the consequences of the resurgence of private secondary schools $(\mathrm{N}=188)$

\begin{tabular}{lcccc}
\hline School managers & $\mathbf{N}$ & $\mathbf{X}$ & S.D. & $\mathbf{t}$ \\
Proprietor of private secondary schools & 96 & 13.6 & 1.3 & \multirow{2}{*}{-8.625} \\
Principals of public secondary schools & 92 & 15.5 & 1.7 & \\
\hline
\end{tabular}

${ }^{*}$ Significant at .05, critical-t $=1.972, \mathrm{df}=186$

The independent t-test statistical procedure was applied in testing this hypothesis. The result of the analysis as presented in table 4 showed that the t-calculated of -8.625 was less than the critical-t value of 1.792 at .05 probabilities level with 186 degrees of freedom. The null hypothesis was therefore retained. This implied that school managers do not significantly differ in their perception of the consequences of the resurgence of private secondary school in the education system in Cross River State.

\section{Discussion of Findings}

The findings of this study show that of the four null hypotheses posed, two were retained while two were rejected. Hypotheses one and four were retained. This implies that managers of public and private secondary schools in Cross River State do not differ significantly in their perception of social factors that influence a boost in private secondary education in the state, and also that the two group of school managers do not differ in their perception on the consequences of a boom on secondary education on the education system in the state.

On the other hand, hypotheses two and three reveal that mangers of secondary schools of the two divide differ significantly in their perception of political and economic factors presented in the research instrument as being the underpinning in the resurgence of private secondary education in the state during the period under study.

The social factors for which there is a convergence of perception of the school managers as giving vent to the resurgence of private secondary schools include inadequate number and spread of public schools, frequent strikes, closure, poor performance indices and inadequate management strategies of public schools, vis-à-vis lack of faith in government and her institutions. In favour of private schools are perceived efficiency, punctuality, regularity, learnerconsciousness and closer ties between management, students and parents.

This goes to show that respondents on the two divides are realistic in their perception of the situation. Several attempts by government at providing mass education in the past have met with problems of inadequacy of funds, facilities and human resources. This was the case in 1957 and 1976 when the Eastern Region of Nigeria and the Federal Republic of Nigeria, respectively, attempted providing mass education for citizens (Fafunwa, 2004, Egbo 2005). In a related study, Ogbiji (2009) found out that majority of public secondary schools in Cross River State lacked adequate student personnel services, thus making them unattractive to students. Enaohwo (2005) found out in Delta state, Nigeria, 
that private secondary schools (438) out-number public schools (374) due to their popular patronage on the basis of their efficiency in management, and that of the 1,103 public primary school, there were 620 privates ones. Result of hypothesis four reveal that respondents do not differ in their perception that the proliferation of private secondary schools in Cross River State has increased access to secondary education, set a stage for competition between public and private schools, stimulated improvement in performance and care of public schools as well as the emergence of many poorly equipped and managed private schools.

Hypotheses two and three sought to determine whether political and economic factors significantly influenced the resurgence of private secondary schools. The result of each shows that the two divide differ significantly in their perception of the factors investigated. The political factors investigated include government liberalization of participation in the provision of educational services, introduction of quality control measures in public schools, non-stringent enforcement of control over private schools and low rate for opening of private schools. A critical examination of the factors seem to indicate that government liberalization of educational services and low rate charged for opening of private schools and the high patronage enjoyed would have been enough incentives for private investors in education. Other baits to private investment in education apparently include pecuniary benefits, availability of cheap labour, successes recorded by existing private schools and increasing demand for private schools (James 1995, Aghenta and Igbinemeka 2005). This goes to show the extent to which parents are willing to sacrifice for their children education (Levin, 2005, Shobhana, Befield, 2001).

The growing trend in the boom in private secondary education is not only applicable to Cross River State. Other states in Nigeria like Akwa Ibom, Delta, Edo and Lagos show similar trends. For example while there are 374 public secondary schools in Delta state the private ones are 438. In Edo State there are 487 public secondary schools and 512 private secondary schools. It is paradoxical that despite the growing poverty and unemployment across Nigeria, parents are still willing to finance their children's education in fee-paying private secondary schools admits free public secondary schools. This is no doubt an indication of parents faith in education as a potent factor in human development and societal progress.

\section{Conclusion}

The result of this study did not come as a surprise. Privatization has become a global phenomenon which the United Nations through the World Bank is championing. From this trend it is envisaged that in the near future private educational institutions at all levels of education will predominate public ones, not only in all the states of Nigeria, but other countries of the world as well. Just as other private sectors of the economy like banking and manufacturing industries have improved on their services to the admiration and patronage of the public, so shall private educational institutions improve on their services and continue to enjoy public support. It is a trend that needs the enabling environment on the part of government to thrive.

\section{Recommendations}

From the findings of this study it has become pertinent to recommend as follows:

1) Since education is key to individual and national development, government should improve the quality of services provided in public secondary schools, not only to make them attractive to students but to enable them achieve the desired objectives.

2) Government control agencies should ensure that facilities in proposed private schools meet minimum requirements before they are allowed to function.

3) To make private schools retain their quality and be affordable to the public, government should provide the enabling environment by giving grants in-aid to them and control the fees they charge.

4) Management and staff of public schools should adopt those management techniques that make private schools more attractive to pupils and parents.

5) Closer partnership in the provision and management of educational services should be developed between government and the private sector. 


\section{References}

Agbenta, J. A. \& Igbineuka, V. O. (2005). "Analysis of parents willingness to demand basic education for children in public/private schools in Edo State". Nigerian Journal of Educational Administration and Planning, 5/2

Befield, C. R. \& Levin, H. M. (2005). "Are private schools more efficient than public schools? A commission paper published by the International Institute for Educational Planning (IIEP).

Cross River State Ministry of Education (2003). School Enrolment Data Planning, research and statistics department, Cross River State Ministry of Education.

Egbo, D. (2005). "The state \& future of education in sub-Saharan Africa: Lesson learned from developed countries. Keynote paper at 2005 Nig. Primary Teacher Education Association, Asaba.

Enaohwo, J. O. (2005). "The welfare cost of education and the private sector initiative". Nigerian journal of educational administration and planning, 5(2).

Fafunwa, A. B. (2004). History of Education in Nigeria, Ibadan UPS. Educational publishers Ltd.

James, E. (1995). "Public-policies toward private education, an international comparison". International Journal of Educational Research, 15.

Obakine, P. A. O. (2003). "Issues in funding universities in Nigeria", National Universities Commission Monograph series 1/7.

Obi, E. (2004). Law and education management. Enugu, Empathy international.

Ogbiji, J. E. (2009). "An evaluation of students personnel services in pubic \& private secondary schools in Cross River State", Unpublished Ph.D Thesis, University of Nigeria, Nsukka.

Ogbonnaya, N. O. (2010.). Principles and application of educational polices in Nigeria, Nsukka, University Trust publishers.

Okunola, P. O. Oyebade, S. A. \& Oladipo, S. A. (2005). Return of schools to private managers in Lagos state. Implication for quality amid change, Nigerian Journal of Educational Administration \& Planning, 5/2.

Onuka, A. O. U. (2005). A comparative study of the quality of managers, teachers and facilities of private \& public primary schools in Ibadan, Oyo State, Nigeria, in Nigerian Journal of Educational Administration and Planning. 5/2.

Onyiuke, M. O. (2000). State versus market: the privatization programme of Nigerian state, in Adebayo, O. O. (ed.). The politics of structural adjustment in Nigeria: Lord James Curvey.

Osador, D. (2005). "Tapping private schools for increase government revenue in Edo State, A reckless voyage". Nigeria journal of Educational Administration and Planning, 5/2.

Shobhana, S. (2001). "Trend in private sector development" in World Bank Education projects, A mimeograph published by the world Bank, Washington, DC.

Tabotndip, J. E. (2010). "Diversity: A Rosance for educational planners and policy makers in the 21st century". In Iloputaife, E.C., Maduewesi, R.B. \& Igbo, R.O. (eds) Issues and challenges in Nigeria education in the $21^{\text {st }}$ century. Onistsha, West \& Solomon Co. Ltd.

Ukeje, B. O. (1992). Educational Administration, Enugu, fourth Dimension pub. Co. 
ISSN 2239-978X

ISSN 2240-0524
Journal of Educational and Social Research MCSER Publishing, Rome-Italy
Vol. 4 No. 6 September 2014 